\title{
Regulation of 11ß-hydroxysteroid dehydrogenase isoforms and glucocorticoid receptor gene expression in the rat uterus
}

\author{
C K M Ho, M Tetsuka and S G Hillier \\ Centre for Reproductive Biology, The University of Edinburgh, 37 Chalmers Street, Edinburgh EH3 9EW, UK \\ (Requests for offprints should be addressed to S G Hillier; Email: s.hillier@ed.ac.uk)
}

\begin{abstract}
Glucocorticoids are known to have diverse effects on the uterus, generally believed to be mediated by the glucocorticoid receptor (GR). To date, two isoforms of the

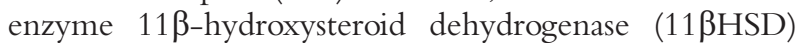
have been identified, namely $11 \beta \mathrm{HSD} 1$ and $11 \beta \mathrm{HSD} 2$, which interconvert active and inactive glucocorticoids and regulate local levels of hormones available to the GR in target tissues. The aim of the present study was to examine the uterine expression of $11 \beta \mathrm{HSD}$ and GR mRNA. The interplay of these parameters is probably an important factor in determining actions of glucocorticoids on the uterus.

Using Northern analysis we investigated the uterine expression of $11 \beta \mathrm{HSD} 1,11 \beta \mathrm{HSD} 2$ and GR mRNA in relation to serum levels of sex steroid hormones and uterine progesterone receptor mRNA expression in an animal model. Immature female rats were treated with 10 IU pregnant mare serum gonadotrophin (PMSG) fol-
\end{abstract}

lowed by $10 \mathrm{IU}$ human chorionic gonadotrophin (hCG) $48 \mathrm{~h}$ afterwards, and then killed at 0, 3, 6, 9, 12 and $24 \mathrm{~h}$ and 5 days after the hCG injection.

Expression of both $11 \beta \mathrm{HSD} 1$ and $11 \beta \mathrm{HSD} 2 \mathrm{mRNA}$ in total uterine RNA was found to be up-regulated by more than $50 \%$ at $48 \mathrm{~h}$ after PMSG injection when oestradiol levels were also high. Following hCG treatment the expression of $11 \beta \mathrm{HSD} 1$ and $11 \beta \mathrm{HSD} 2$ further increased to reach maximal levels at 24 and $12 \mathrm{~h}$ respectively. GR mRNA expression was down-regulated by more than $50 \%$ by PMSG but gradually recovered after hCG injection. The results show that mRNA expression of $11 \beta \mathrm{HSD} 1$, $11 \beta$ HSD2 and GR in the uterus is developmentally regulated, suggesting that these key determinants of glucocorticoid action may play an important role in uterine function.

Journal of Endocrinology (1999) 163, 425-431

\section{Introduction}

Glucocorticoids have a wide range of effects on many organs and tissues. Pharmacological doses of glucocorticoids were shown to suppress the hypothalamicpituitary-gonadal axis both in humans (Quigley \& Yen 1980) and in the rat (Rivier \& Vale 1984). They are also known to alter uterine responses to oestrogens. Glucocorticoids have been reported to suppress oestrogenstimulated uterine blood flow, weight gain, synthesis of DNA and proliferation in the uterus (Campbell 1978, Monheit \& Resnik 1981). However, Gunin (1998) recently demonstrated that triamcinolone treatment caused an increase in oestradiol-induced proliferation of stromal cells in the endometrium. The concentration of uterine oestrogen receptors, on the other hand, can be down-regulated by the administration of glucocorticoids (Atkinson \& Adams 1988, Rabin et al. 1990).

Uterine events such as menstruation, implantation, cervical softening and parturition have a lot of similarities with non-reproductive inflammatory situations (Kelly
1996). At high concentrations, glucocorticoids inhibit most immunological responses and are well-known antiinflammatory agents. It is thus likely that they participate in each of the above uterine events. For instance, synthesis of prostaglandins, known participants in inflammatory situations, was shown to be modulated by glucocorticoids in the uterus (Pakrasi et al. 1983).

Regulation of the actions of glucocorticoids is achieved by a number of mechanisms. Pituitary adrenocorticotrophic hormone maintains blood levels of glucocorticoids in balance. In plasma, cortisol and corticosterone bind to corticosteroid-binding globulin (CBG) and albumin. Plasma levels of CBG thus regulate the bioavailability of free glucocorticoids. At the cellular level, hormone availability to the glucocorticoid receptor (GR) is regulated by the expression of $11 \beta$-hydroxysteroid dehydrogenase (11ßHSD). Two isoforms of this enzyme have been identified (Monder \& Shackleton 1984, Brown et al. 1993), namely type 1 (11ßHSD1) and type 2 (11ßHSD2). $11 \beta$ HSD1 is widely distributed (Whorwood et al. 1992). Though the precise physiological role of $11 \beta \mathrm{HSD} 1$ is 
currently unclear, it has been suggested to play a role in maintaining expression of glucocorticoid-regulated genes (Jamieson et al. 1999). It is a bi-directional, NADPdependent enzyme with predominant 11-ketoreductase activity and a low binding affinity for the active glucocorticoids cortisol and corticosterone (Lakshmi \& Monder 1988, Monder \& Lakshmi 1990, Stewart \& Mason 1995). $11 \beta \mathrm{HSD} 2$, in contrast, is NAD-dependent and has strong $11 \beta$-dehydrogenase activity and high binding affinity for cortisol and corticosterone. It inactivates cortisol to cortisone in the human and corticosterone to 11dehydrocorticosterone in the rat (Albiston et al. 1994, Stewart et al. 1994, Brown et al. 1996).

Glucocorticoid action on its target tissues depends not only on levels of active steroid that can gain access to the tissues, but also on GR levels and the local glucocorticoid metabolism profile. GR is a member of the steroid-thyroid hormone receptor superfamily (Evans 1988, Funder 1993). Classically, actions of glucocorticoids are mediated via GR, which interacts with specific hormone response elements (HREs) or other transcription factors to regulate gene transcription (Bamberger et al. 1996). To date, little is known about how the interaction of the above parameters is related to uterine function. In this study, we investigated the regulation of the uterine $11 \beta \mathrm{HSD}$ system and GR in relation to plasma levels of ovarian steroid hormones in a rat model.

\section{Materials and Methods}

\section{Animals and treatment}

Immature female rats of the Wistar strain between 21 and 25 days of age were housed in a temperature-controlled room illuminated for $12 \mathrm{~h} /$ day. The animals had free access to rat chow and water.

Rats were injected s.c. with $10 \mathrm{IU}$ of pregnant mare serum gonadotrophin (PMSG; Sigma Chemical Co., Poole, Dorset, UK) followed by s.c. injection of $10 \mathrm{IU}$ human chorionic gonadotrophin (hCG; Sigma) $48 \mathrm{~h}$ after PMSG treatment. These animals were then killed at 0, 3, $6,9,12$ and $24 \mathrm{~h}$ and 5 days after the hCG injection. Control animals were killed when hCG was injected to other animals which had received PMSG. With this treatment, ovulation was noted to take place around $12 \mathrm{~h}$ after hCG injection. At 5 days, numerous copora lutea were present in the ovaries.

Collected uteri were kept on ice in PBS. They were cleaned under a dissection microscope and then deep frozen in liquid nitrogen. All animal handling and treatment complied with guidance issued by the UK Home Office. Uteri from groups of 4-13 animals were pooled together to give sufficient material for Northern blot analysis. Serum samples were obtained from randomly selected animals to determine oestradiol and progesterone levels.

\section{Hormone assays}

Oestradiol assays were performed as described previously (Hillier \& De Zwart 1981). The intra-assay coefficient of variation was less than $10 \%$. Plasma progesterone levels were determined with a solid-phase RIA kit (Coat-ACount, Diagnostic Products Corporation, Los Angeles, CA, USA).

\section{$R N A$ preparation}

Frozen uterine samples were homogenized in ice-cold $4 \mathrm{M}$ guanidinium thiocyanate solution containing $25 \mathrm{mM}$ sodium citrate, $0.5 \%(\mathrm{w} / \mathrm{v})$ sarcosyl and $0.1 \mathrm{M} \beta$ mercaptoethanol (all from Sigma). Total RNA was extracted with phenol-chloroform as previously described (Chomczynski \& Sacchi 1987), dissolved in formamide and kept at $-70{ }^{\circ} \mathrm{C}$ until Northern blot analysis.

\section{cDNA templates and ${ }^{32}$ P-labelled riboprobes}

Reverse transcription PCR (RT-PCR) generated the required DNA templates. Oligonucleotide primer pairs were obtained from Cruachem (Glasgow, UK). Singlestrand cDNA of $11 \beta \mathrm{HSD} 1$ was reverse transcribed from total RNA obtained from immature rat kidney, whereas $11 \beta$ HSD 2 and GR cDNAs were from immature rat liver using Moloney murine leukemia virus reverse transcriptase (Stratagene Cloning Systems, La Jolla, CA, USA) at $37^{\circ} \mathrm{C}$ for $60 \mathrm{~min}$. The resultant templates underwent PCR amplification (30 cycles) with Pfu-DNA polymerase (Stratagene). Each PCR cycle consisted of denaturing for $45 \mathrm{~s}$ at $94{ }^{\circ} \mathrm{C}$, annealing for $45 \mathrm{~s}$ at $60^{\circ} \mathrm{C}$ and $2 \mathrm{~min}$ extension at $72{ }^{\circ} \mathrm{C}$ with the final extension for $10 \mathrm{~min}$. The resultant PCR products were then cloned using a pCR-Script Amp SK $(+)$ Cloning Kit (Stratagene) and sequenced to verify the authenticity of the products. The sizes of the templates were: 11ßHSD1, $620 \mathrm{bp}$ (nucleotides (nt) 109-728; Agarwal et al. 1989, GenBank accession no. J05107); 11ßHSD2, 412 bp (nt 534-945; Zhou et al. 1995, GenBank accession no. U22424); and GR 772 bp (nt 1383-2154; Miesfeld et al. 1986, GenBank accession no. M14053). 18S rRNA was synthesized from cDNA containing the $80 \mathrm{bp}$ fragment of a highly conserved region of human 18S rRNA (pT7 RNA 18S; Ambion, Austin, TX, USA). All RT-PCR-generated cDNAs were linearized with either EcoRI or NotI restriction enzyme (Promega, Madison, WI, USA).

The cDNA template of rat progesterone receptor (PR1) was generously provided by Dr Ok-Kyong Park-Sarge, University of Kentucky. This cDNA (approximately $550 \mathrm{bp}$ ) encodes the hormone-binding domain of the rat PR (Park \& Mayo 1991).

All RNA probes were labelled with UTP $(3000 \mathrm{Ci} /$ mmol for 11ßHSD1, 11ßHSD2, GR and PR; $800 \mathrm{Ci} / \mathrm{mmol}$ for $18 \mathrm{~S}$; Amersham International, 
Aylesbury, Bucks, UK) using either T3 or T7 RNA polymerase and reagents supplied by Promega.

\section{Northern blot analysis}

Total RNA (20 $\mu \mathrm{g}$ per lane) was size fractionated by electrophoresis in $1 \%(\mathrm{w} / \mathrm{v})$ agarose gel containing $2 \cdot 2 \mathrm{M}$ formaldehyde at $75 \mathrm{~V}$ for $3 \cdot 5 \mathrm{~h}$. Following electrophoresis, RNA was transferred onto a nylon membrane (Boehringer Mannheim, Mannheim, Germany) overnight in $20 \times$ standard saline citrate (SSC; single-strength SSC $=0 \cdot 15 \mathrm{M}$ $\mathrm{NaCl}$ and $0 \cdot 015 \mathrm{M}$ sodium citrate) and then covalently cross-linked to the membrane by ultraviolet irradiation. Ethidium bromide staining confirmed the presence of undegraded $18 \mathrm{~S}$ and $28 \mathrm{~S}$ rRNA. RNA from three different sets of animals was run on gels to give nylon membranes in triplicate.

The nylon membranes were prehybridized and hybridized as described by Church \& Gilbert (1984) with minor modifications. The prehybridization/hybridization solution consisted of $0.2 \mathrm{M}$ sodium phosphate $(\mathrm{pH} 7 \cdot 2)$, $1 \mathrm{mM}$ EDTA, 1\%(w/v) BSA, 7\% (w/v) SDS and 45\% $(\mathrm{v} / \mathrm{v})$ deionized formamide. Prehybridization was carried out for $2 \mathrm{~h}$ at 60 or $65^{\circ} \mathrm{C}$ and hybridization for $18-24 \mathrm{~h}$ at the same temperature. Radiolabelled RNA probes were then added to the hybridization solution at a concentration of $1 \times 10^{6}$ c.p.m. $/ \mathrm{ml}\left(0.5 \times 10^{6}\right.$ c.p.m. $/ \mathrm{ml}$ for the $18 \mathrm{~S}$ probe). Membranes were washed in stringency wash solution containing $40 \mathrm{mM}$ sodium phosphate, $1 \mathrm{mM}$ EDTA and 1\% (w/v) SDS, twice at room temperature $\left(5 \mathrm{~min}\right.$ ), followed by two $30 \mathrm{~min}$ washes at 60 or $65^{\circ} \mathrm{C}$. After autoradiography, the membranes were stripped by washing twice in boiling $0 \cdot 1 \%$ SDS solution for $30 \mathrm{~min}$ at room temperature and rinsed briefly in $2 \times$ SSC. They were then re-probed with another ${ }^{32} \mathrm{P}$-labelled riboprobe.

\section{Data analysis}

Quantification of radioactive signals of RNA by electronic autoradiography (Instant Imager, Packard, Downers Grove, IL, USA) was followed by exposure of the membranes to Kodak XAR-5 film (Eastman Kodak, Rochester, NY, USA) with intensifying screens for $16-48 \mathrm{~h}$ at $-70{ }^{\circ} \mathrm{C}$. The abundance of mRNA was normalized to the $18 \mathrm{~S}$ rRNA signal. Results were finally expressed as percentages of the control values and analysed using one-way ANOVA with a paired Student's $t$-test.

\section{Results}

\section{Steroid hormone levels}

To establish the relationship between ovarian steroid hormones and glucocorticoid response parameters, levels of serum oestradiol and progesterone were measured at each

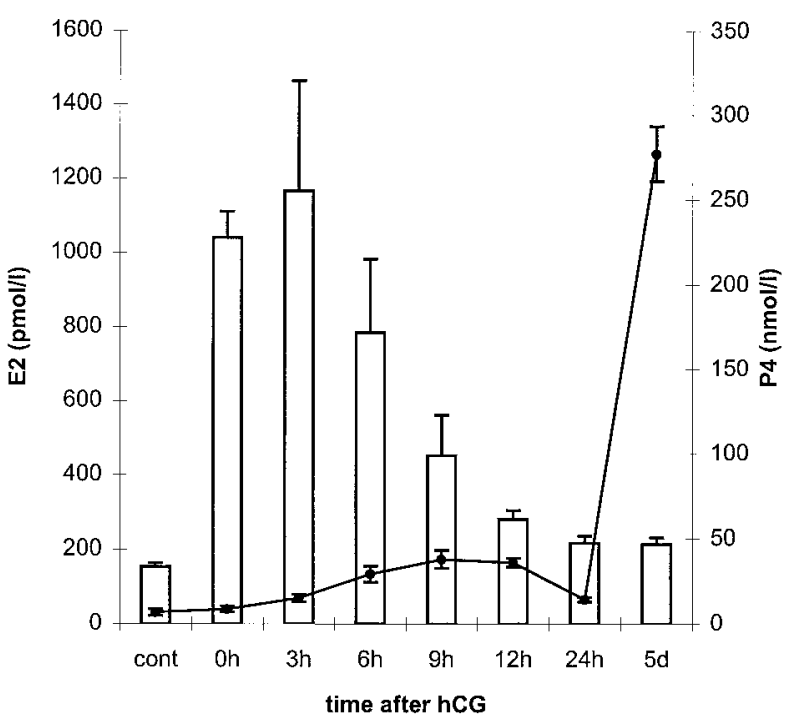

Figure 1 Serum oestradiol (E2) (bars) and progesterone (P4) (line) levels in the experimental animals. Immature female Wistar rats (21-25 days old) were treated with 10 IU PMSG followed by $10 \mathrm{IU}$ hCG $48 \mathrm{~h}$ afterwards. Animals were killed at 0, 3, 6, 9, 12 and $24 \mathrm{~h}$ and 5 days after the hCG injection. Control animals (cont) were killed at the time of hCG injection to other experimental animals. Mean \pm S.E.M $(n=4)$.

point of uterine collection. As shown in Fig. 1, the serum steroid hormone levels mimicked the changes that occur in the rat oestrous cycle, with an initial increase in oestradiol, followed by a secondary rise in progesterone around the time of ovulation at $12 \mathrm{~h}$ after hCG treatment.

\section{Expression of $P R m R N A$ in total uterine $R N A$}

Uterine PR mRNA levels closely followed the changes in serum oestradiol levels, with peak PR mRNA expression at 0 and $3 \mathrm{~h}$ coinciding with peak serum concentrations of oestradiol, whereas high serum levels of progesterone at 9 and $12 \mathrm{~h}$ and 5 days after hCG were associated with relatively low expression of PR mRNA (Figs 2 and 3).

\section{Expression of 11ßHSD1, 11ßHSD2 and GR mRNA in total uterine RNA}

Expression of both $11 \beta \mathrm{HSD} 1$ and $11 \beta \mathrm{HSD} 2 \mathrm{mRNA}$ (Figs 4 and $5 \mathrm{~A}$ ) increased by more than $50 \%$ at $48 \mathrm{~h}$ after PMSG treatment when oestradiol levels were also high. Thereafter, $11 \beta \mathrm{HSD} 1 \mathrm{mRNA}$ levels rose gradually to approximately three times the control values at $24 \mathrm{~h}$ after hCG injection.

Changes of $11 \beta \mathrm{HSD} 2 \mathrm{mRNA}$ levels followed a pattern slightly dissimilar to that of $11 \beta \mathrm{HSD} 1 \mathrm{mRNA}$ levels. Up-regulation of $11 \beta \mathrm{HSD} 2 \mathrm{mRNA}$ expression to more than $250 \%$ of the control values at $12 \mathrm{~h}$ after hCG, i.e. $9 \mathrm{~h}$ 


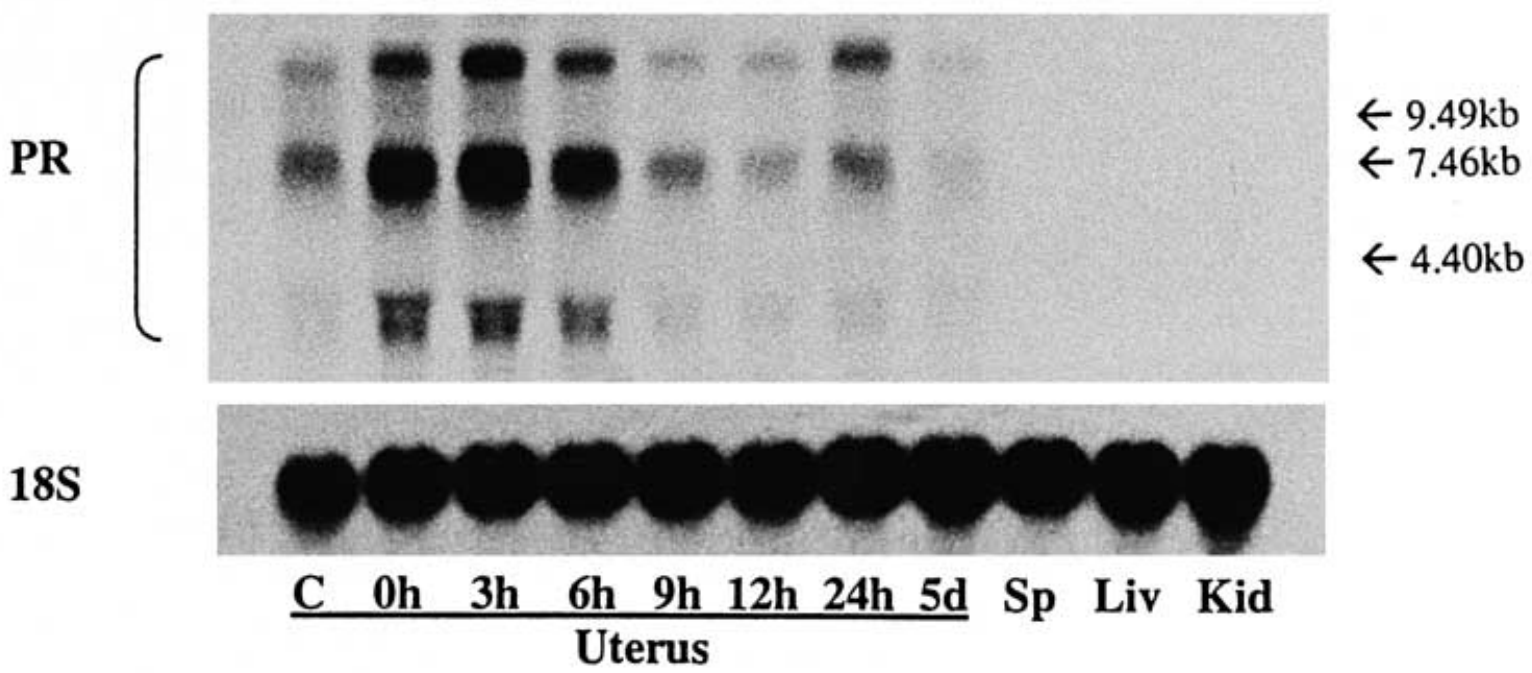

Figure 2 Expression of PR mRNA in total uterine RNA: autoradiogram of Northern blot analysis. Duration of film exposure: PR, $16 \mathrm{~h} ; 18 \mathrm{~S}, 17 \mathrm{~h}$. Similar loading of total RNA was confirmed by similar intensity of the $18 \mathrm{~S}$ rRNA band in each lane. PR mRNA expression in spleen (Sp), liver (Liv) and kidney (Kid) was insignificant. C=control.

after peak serum oestradiol levels had been reached, was followed by a sharp decrease at $24 \mathrm{~h}$.

The pattern of GR mRNA expression (Fig. 5B) bore no direct relationship with the patterns of $11 \beta \mathrm{HSD} 1$ and $11 \beta \mathrm{HSD} 2$ mRNA levels but appeared to be inversely related to circulating levels of oestradiol. GR mRNA expression decreased by more than 50\% after PMSG

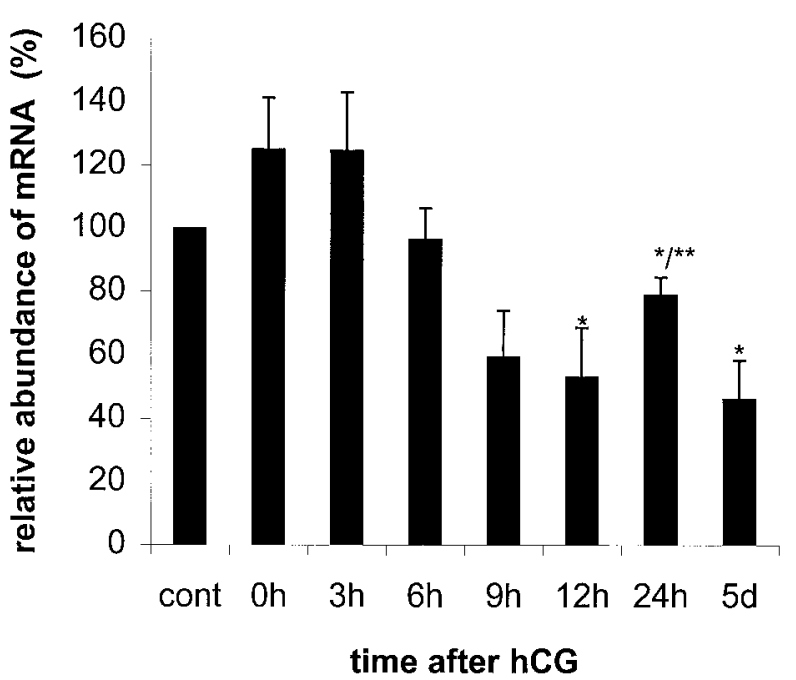

Figure 3 Quantitative analysis of PR mRNA expression. Mean \pm S.E.M. $(n=3)$. Values significantly different from the controls are marked * $(P<0.05)$. The value at $24 \mathrm{~h}$ is significantly different from that at 5 days $(* *, P<0 \cdot 05)$. cont $=$ control. treatment and gradually increased thereafter to approximately $75 \%$ of the control values at 5 days after hCG.

\section{Discussion}

The present study demonstrates that PR, 11ßHSD1, $11 \beta \mathrm{HSD} 2$ and GR mRNA expression is developmentally regulated in the rat uterus. These results show a hitherto unknown relationship between parameters of uterine glucocorticoid responsiveness and uterine functional status, as detected by circulating ovarian steroid hormone levels. Changes in serum concentrations of oestradiol and progesterone in the current animal model mimicked those of the rat oestrous cycle. Peak oestradiol levels at $3 \mathrm{~h}$ after hCG were followed $6 \mathrm{~h}$ afterwards by peak progesterone levels. This sequence can be likened to the pro-oestrus midday oestradiol surge followed by a surge of progesterone in the late afternoon (Butcher et al. 1974, Smith et al. 1975). The high serum concentrations of progesterone at 5 days after hCG, presumably secreted from the numerous corpora lutea noticed at that time, can be likened to those found during pseudopregnancy.

To ascertain if uterine tissues of the animals responded to various steroid hormone levels as predicted from reported studies (Kraus \& Katzenellenbogen 1993, Graham \& Clarke 1997), we investigated uterine PR mRNA expression. It is known that uterine PR expression can be increased by oestrogen administration, whereas progesterone down-regulates PR expression in the cycling rat. In our animal model, the pattern of PR mRNA levels 


\section{1ßHSD1}

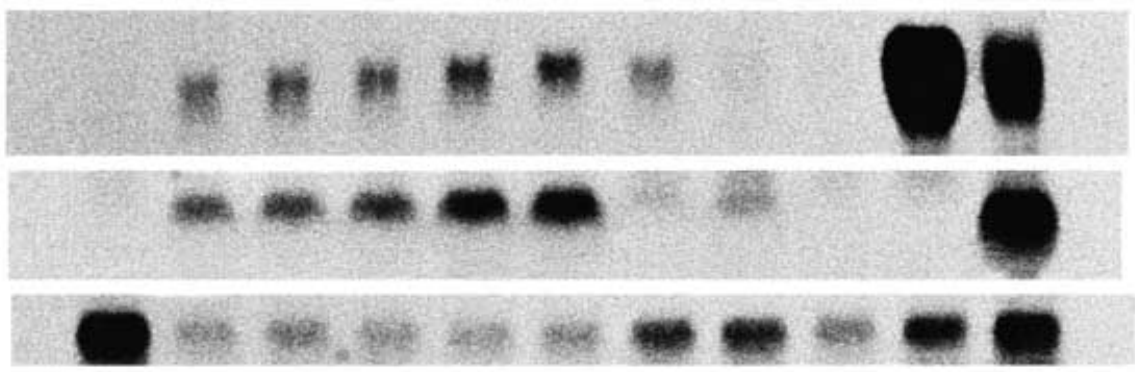

11ßHSD2

\section{GR}

$18 \mathrm{~S}$

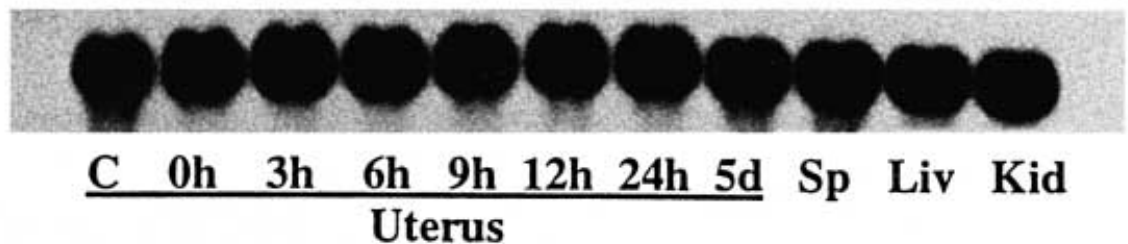

Figure 4 Expression of $11 \beta \mathrm{HSD} 1,11 \beta \mathrm{HSD} 2$ and GR mRNA in total uterine RNA: autoradiogram of Northern blot analysis. Duration of film exposure: $11 \beta \mathrm{HSD} 1,48 \mathrm{~h} ; 11 \beta \mathrm{HSD} 2,19 \mathrm{~h}$; GR, $21 \mathrm{~h} ; 18 \mathrm{~S}, 17 \mathrm{~h}$. Similar loading of total RNA was confirmed by similar intensity of the $18 \mathrm{~S}$ rRNA band in each lane. Sp, spleen (negative control); Liv, liver (positive

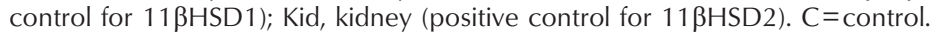

confirmed that the changing hormonal environment modulated PR mRNA expression in the experimental animals in a predicted manner. We detected at least three separate bands of PR mRNA in the uterus, the sizes of which correspond to those reported in the literature (Kraus \& Katzenellenbogen 1993).

The effects of gonadotrophins on uterine function are mediated by ovarian steroid hormones but the influence of which on the uterine $11 \beta \mathrm{HSD}$ system remains unclear. Burton et al. (1998) showed that immunoreactivity for $11 \beta$ HSD1 found in uterine homogenates from ovariectomized rats was increased by oestrogen replacement with or without progesterone. Progesterone replacement alone had no effect on the uterine $11 \beta \mathrm{HSD} 1$ signal. The same study reported that immunoreactivity for $11 \beta \mathrm{HSD} 2$ was increased by oestrogen replacement, whereas progesterone replacement alone had a slight stimulatory effect on $11 \beta \mathrm{HSD} 2$ immunostaining in stromal cells. Another study (Albiston et al. 1995), however, demonstrated in the cycling rat that at proestrus when circulating levels of oestrogen were high, 11ßHSD1 mRNA expression began to fall and did not rise again until metoestrus when oestrogen levels were significantly lower. In our study, PMSG treatment up-regulated mRNA expression of both $11 \beta \mathrm{HSD}$ isoforms, most likely an indirect effect via rising oestradiol levels. Yet falling oestradiol levels between 3 and $12 \mathrm{~h}$ after hCG treatment were not associated with a corresponding decrease in either $11 \beta \mathrm{HSD} 1$ or $11 \beta \mathrm{HSD} 2$ mRNA expression. It is noteworthy that the increasing

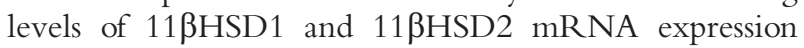
between 3 and $12 \mathrm{~h}$ after hCG coincided with the early rise of serum progesterone concentrations. However, high progesterone levels at 5 days were not associated with high
$11 \beta \mathrm{HSD} 1$ or $11 \beta \mathrm{HSD} 2 \mathrm{mRNA}$ expression. Therefore a direct effect of progesterone on uterine $11 \beta \mathrm{HSD}$ mRNA expression remains to be established. The demonstration that expression of $11 \beta \mathrm{HSD}$ mRNA is related to ovarian hormone changes does not necessarily mean that enzyme protein or activity in the uterus follows a similar pattern. It should be borne in mind that the half-life of $11 \beta \mathrm{HSD}$ mRNA could affect tissue levels of mRNA and enzyme protein concentrations in the uterus. Translational and post-translational regulations are also potential factors in determining the local $11 \beta \mathrm{HSD}$ protein concentrations.

The implication of our results is that both activation of glucocorticoid through $11 \beta \mathrm{HSD}$ enzyme activity and levels of GR are likely to have roles in modulating glucocorticoid action in the uterus. The changes in GR mRNA expression in this study (Fig. 5B) followed a pattern different from those of $11 \beta \mathrm{HSD} 1$ and $11 \beta \mathrm{HSD} 2$. To our knowledge, this is the first time that PMSG treatment has been shown to down-regulate uterine GR mRNA expression in the immature rat. The downregulation of GR mRNA after PMSG could be attributed to direct or indirect suppression of GR mRNA transcription by the rising oestradiol levels. An alternative explanation is a non-proportional increase in the number of cells with low expression of GR mRNA relative to the number of cells with high expression, leading to an apparent down-regulation of GR mRNA expression in total uterine RNA.

The dissimilar patterns of the above glucocorticoid response parameters suggest that it is the interaction of the local $11 \beta$ HSD system and GR expression which determines uterine response to glucocorticoids. Uterine events such as menstruation, implantation, cervical softening and 

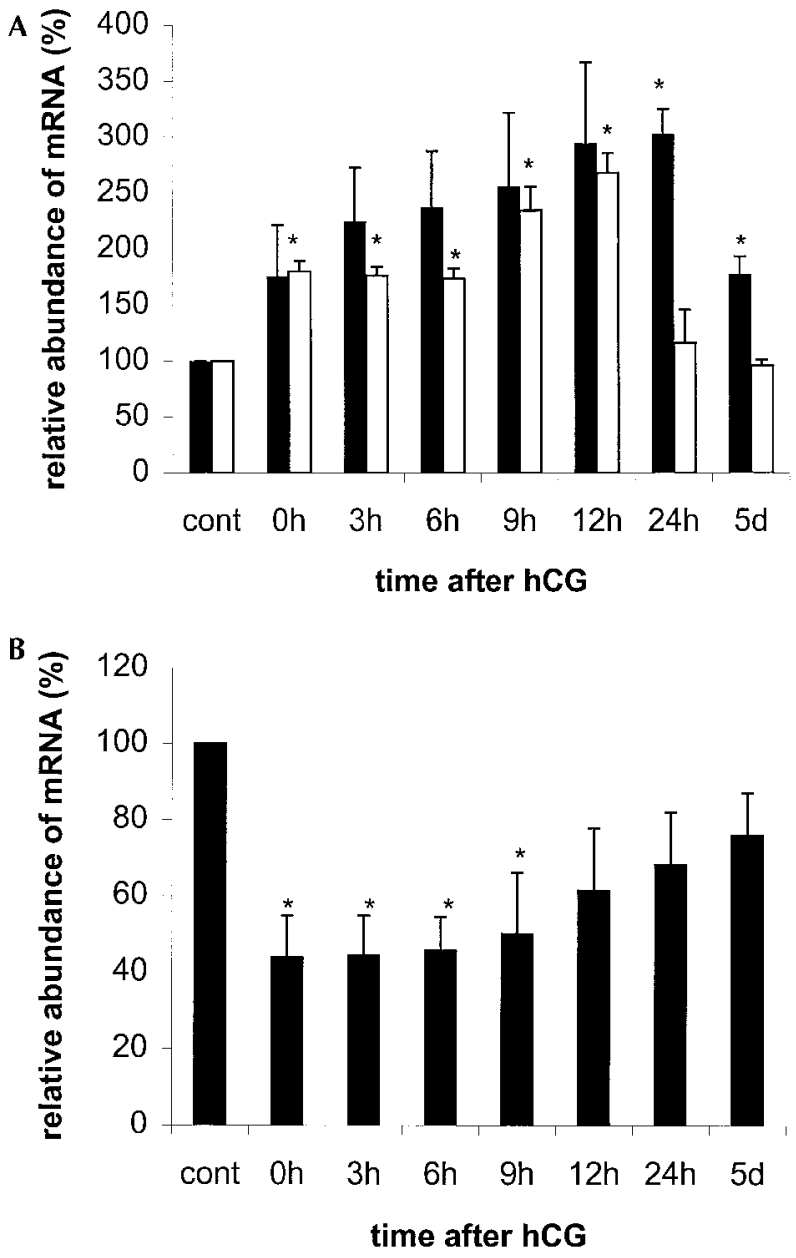

Figure 5 Quantitative analysis of expression of (A) 11ßHSD1 (filled bars) and 11 $\beta$ HSD2 (open bars) mRNA and (B) GR mRNA. Mean \pm S.E.M. $(n=3)$. Values significantly different from the controls are marked $*(P<0 \cdot 05)$.

parturition have a lot of similarities with non-reproductive inflammatory processes (Kelly 1996). By virtue of their well-known anti-inflammatory actions, glucocorticoids are potentially important regulators of these uterine processes. At $24 \mathrm{~h}$ after $\mathrm{hCG}$, when most of the animals had ovulated, the up-regulation of $11 \beta \mathrm{HSD} 1 \mathrm{mRNA}$ compared with the relatively low $11 \beta \mathrm{HSD} 2$ mRNA expression (Fig. 5A) could result in an accumulation of active glucocorticoids in the uterus. This is attributed to the fact that the major action of $11 \beta \mathrm{HSD} 2$ is inactivation of active glucocorticoids. GR mRNA expression was also relatively high at this time. Whether these active glucocorticoids prepare the uterus at this stage for implantation awaits further investigations.

Besides GR, PR is also implicated in the mediation of glucocorticoid anti-inflammatory effects. Steroid hormone receptors modulate transcription of target genes by interacting with HREs on chromosomes. Studies have shown that both GR and PR can recognize and bind to the same HRE (Strähle et al. 1987, Tsai et al. 1988). Strähle et al. (1989) suggested that the lack of PR in the liver prevents progestins from activating glucocorticoidresponsive genes and that differential expression of hormone receptors is a mechanism by which steroid-specific gene activation is achieved. However, in organs coexpressing both GR and PR, e.g. the uterus, the mechanism by which hormone-specific transcription is achieved is still not fully understood, though mechanisms involving interaction of GR with other transcription factors in the absence of specific HRE binding have been described (Bamberger et al. 1996).

Our study confirms that the rat uterus expresses both GR and PR. Between 9 and $12 \mathrm{~h}$ after hCG, high serum progesterone concentrations coincided with peak $11 \beta \mathrm{HSD} 2 \mathrm{mRNA}$ expression. A speculative function of $11 \beta \mathrm{HSD} 2$ in the uterus during this period is the exclusion of active glucocorticoids from binding to GR. Progesterone-bound PR could therefore selectively modulate gene transcription via the non-selective HREs. Metabolism of active glucocorticoids by $11 \beta \mathrm{HSD} 2$ might provide a means of promoting progesterone specificity in tissues such as the uterus that co-express PR and GR.

In conclusion, we have shown that the rat uterus expresses key components of the glucocorticoid response system $-11 \beta \mathrm{HSD}$ types 1 and 2 , and GR - all of which are developmentally regulated in response to gonadotrophin treatment. The patterns of response suggest that the ovarian steroids oestradiol and progesterone mediate some if not all of these changes. Further studies are required to substantiate the role of oestradiol and progesterone in the regulation of these parameters of glucocorticoid response and to delineate their physiological importance.

\section{Acknowledgements}

We thank Miss Martha Urquhart for the hormone assays and Professor Hilary Critchley for helpful discussions. This work was supported by a UK Medical Research Council Programme Grant, No. 8929853.

\section{References}

Agarwal AK, Monder C, Eckstein B \& White PC 1989 Cloning and expression of rat cDNA encoding corticosteroid $11 \beta$-dehydrogenase. Journal of Biological Chemistry 264 18939-18943.

Albiston AL, Obeyesekere VR, Smith RE \& Krozowski ZS 1994 Cloning and distribution of the human $11 \beta$-hydroxysteroid dehydrogense type 2 enzyme. Molecular and Cellular Endocrinology 105 R11-R17.

Albiston AL, Smith RE \& Krozowski ZS 1995 Changes in the levels of $11 \beta$-hydroxysteroid dehydrogense mRNA over the oestrous cycle in the rat. Journal of Steroid Biochemistry and Molecular Biology 52 45-48. 
Atkinson S \& Adams NR 1988 Adrenal glands alter the concentration of oestradiol-17 $\beta$ and its receptor in the uterus of ovariectomized ewes. Journal of Endocrinology 118 375-380.

Bamberger CM, Schulte HM \& Chrousos GP 1996 Molecular determinants of glucocorticoid receptor function and tissue sensitivity to glucocorticoids. Endocrine Reviews 17 245-261.

Brown RW, Chapman KE, Edwards CRW \& Seckl JR 1993 Human placental 11 $\beta$-hydroxysteroid dehydrogenase: evidence for and partial purification of a distinct NAD-dependent isoform. Endocrinology 132 2614-2621.

Brown RW, Chapman KE, Murad P, Edwards CRW \& Seckl JR 1996 Purification of $11 \beta$-hydroxysteroid dehydrogenase type 2 from human placenta utilizing a novel affinity labelling technique. Biochemical Journal 313 997-1005.

Burton PJ, Krozowski ZS \& Waddell BJ 1998 Immunolocalization of $11 \beta$-hydroxysteroid dehydrogenase types 1 and 2 in rat uterus. Endocrinology 139 376-382.

Butcher RL, Collins WE \& Fugo NW 1974 Plasma concentration of $\mathrm{LH}, \mathrm{FSH}$, prolactin, progesterone and estradiol-17 $\beta$ throughout the 4-day estrous cycle of the rat. Endocrinology 94 1704-1708.

Campbell PS 1978 The mechanism of the inhibition of uterotrophic response by acute dexamethasone pretreatment. Endocrinology 103 716-723.

Chomczynski P \& Sacchi N 1987 Single step method of RNA isolation by acid guanidinium thiocyanate-phenol-chloroform extraction. Analytical Biochemistry 162 156-159.

Church GM \& Gilbert W 1984 Genomic sequencing. Proceedings of the National Academy of Sciences of the USA 8 1991-1995.

Evans RM 1988 The steroid and thyroid hormone receptor superfamily. Science 240 889-895.

Funder JW 1993 Mineralocorticoids, glucocorticoids, receptors and response elements. Science 259 1132-1133.

Graham JD \& Clarke CL 1997 Physiological action of progesterone in target tissues. Endocrine Reviews 18 502-515.

Gunin AG 1998 Effect of long-term glucocorticoid treatment on oestradiol-induced proliferation in the uterus of ovariectomized rats. Journal of Endocrinology 157 481-488.

Hillier SG \& De Zwart FA 1981 Evidence that granulosa cell aromatase induction/activation by FSH is an androgen receptorregulated process in vitro. Endocrinology 109 1303-1305.

Jamieson PM, Nyirenda MJ, Walker BR, Chapman KE \& Seckl JR 1999 Interactions between oestradiol and glucocorticoid regulatory effects on liver-specific glucocorticoid-inducible genes: possible evidence for a role of hepatic $11 \beta$-hydroxysteroid dehydrogenase type 1. Journal of Endocrinology 160 103-109.

Kelly RW 1996 Inflammatory mediators and parturition. Reviews of Reproduction 1 89-96.

Kraus WL \& Katzenellenbogen BS 1993 Regulation of progesterone receptor gene expression and growth in the rat uterus: modulation of estrogen actions by progesterone and sex steroid hormone antagonists. Endocrinology 132 2371-2379.

Lakshmi V \& Monder C 1988 Purification and characterization of the corticosteroid $11 \beta$-dehydrogense component of the rat liver $11 \beta$-hydroxysteroid dehydrogense complex. Endocrinology 123 2390-2398.

Miesfeld R, Rusconoi S, Godowski PJ, Maler BA, Okret S, Wilstrom AC, Gustafsson JA \& Yamamoto KR 1986 Genetic complementation to a glucocorticoid receptor deficiency by expression of cloned receptor cDNA. Cell 46 389-399.

Monder C \& Lakshmi V 1990 Corticosteroid 11 $\beta$-dehydrogense of rat tissues: immunological studies. Endocrinology 126 2435-2443.

Monder C \& Schakleton CHL $198411 \beta$ Hydroxysteroid dehydrogense: fact or fancy? Steroids 44 383-417.

Monheit AG \& Resnik R 1981 Corticosteroid suppression of oestrogen-induced uterine blood flow in nonpregnant sheep. American Journal of Obstetrics and Gynecology 139 454-458.

Pakrasi PL, Cheng HC \& Dey SK 1983 Prostaglandins in the uterus: modulation by steroid hormones. Prostaglandins 26 991-1009.

Park O-K \& Mayo KE 1991 Transient expression of progesterone receptor messenger RNA in ovarian granulosa cells after the preovulatory luteinizing hormone surge. Molecular Endocrinology $\mathbf{5}$ 967-978.

Quigley ME \& Yen SSC 1980 The role of endogenous opioids in LH secretion during the menstrual cycle. Journal of Clinical Endocrinology and Metabolism 51 179-181.

Rabin DS, Johnson EO, Brandon DD, Liapi C \& Chrousos GP 1990 Glucocorticoids inhibit estradiol-mediated uterine growth: possible role of the uterine estradiol receptor. Biology of Reproduction $\mathbf{4 2}$ $74-80$.

Rivier C \& Vale W 1984 Influence of corticotrophin-releasing factor on reproductive functions in the rat. Endocrinology 114 914-921.

Smith MS, Freeman ME \& Neill JD 1975 The control of progesterone secretion during the estrous cycle and early pseudopregnancy in the rat. Endocrinology 96 219-226.

Stewart PM \& Mason JI 1995 Cortisol to cortisone - glucocorticoid to mineralocorticoid. Steroids 60 143-146.

Stewart PM, Murry BA \& Mason JI 1994 Human kidney $11 \beta$-hydroxysteroid dehydrogense is a high afffinity NADdependent enzyme and differs from the cloned type 1 isoform. Journal of Clinical Endocrinology and Metabolism 79 480-484.

Strähle U, Klock G \& Schutz G 1987 A DNA sequence of 15 base pairs is sufficient to mediate both glucocorticoid and progesterone induction of gene expression. Proceedings of the National Academy of Sciences of the USA 84 7871-7875.

Strähle U, Boshart M, Klock G, Stewart F \& Schutz G 1989 Glucocorticoid- and progesterone-specific effects are determined by differential expression of the respective hormone receptors. Nature $339629-632$.

Tsai SY, Carlstedtduke J, Weigel NL, Dahlman K, Gustafsson JA, Tsai MJ \& Omalley BW 1988 Molecular interactions of steroid hormone receptor with its enhancer element - evidence for receptor dimer formation. Cell 55 361-369.

Whorwood CB, Franklyn JA, Sheppard MC \& Stewart PM 1992 Tissue localization of $11 \beta$-hydroxysteroid dehydrogense and its relationship to the glucocorticoid receptor. Journal of Steroid Biochemistry and Molecular Biology 41 21-28.

Zhou MY, Gomezsanchez EP, Cox DL, Cosby D \& Gomezsanchez CE 1995 Cloning, expression, and tissue distribution of the rat nicotinamide adenine dinucleotide-dependent $11 \beta$-hydroxysteroid dehydrogenase. Endocrinology 136 3729-3734.

Received 5 May 1999

Accepted 9 August 1999 